\title{
Investigation the relationship of type $D$ personality and it's sub-scales with depression in female students of senior high school grade at Shahin shahr
}

\author{
Nemat Allah Yarollahi ${ }^{1^{*}}$, Mahtab Rahimi ${ }^{2}$, Aram Khabaz Shirazi ${ }^{3}$ \\ 1- M.A in clinical psychology, Shahed University, Tehran, Iran. (Corresponding Author) \\ n.yaralahi@yahoo.com \\ 2- M.A student of clinical psychology, Shahid Chamran University, Ahvaz, Iran. \\ 3- Ph.D. student of psychology, Azad Islamic University of Khorasgan, Isfahan, Iran
}

\begin{abstract}
Introduction: Depression is one of the most prevalent and disabling problems in adolescence. Researches have shown that personality traits can predict mood changes over the time, and some personality traits are more susceptible to mental disorder compare to the others.
\end{abstract}

Aim: The aim of the current study was investigation of the relationship between type D personality and it's sub-scales (Negative Affect and Social Inhibition) with depression in female students of senior high school grade.

Method: This is a cross-sectional descriptive study. The statistical population of the study was all of female students of senior high school grade studying in an academic year (20162017) at Shahin Shahr. The number of 126 students were selected via multi-stage cluster sampling method.

Tool: Tools that are used in this study were Denollet type D personality questionnaire, and Beck-II depression Inventory. The data was analyzed by using Pearson correlation coefficient and stepwise multiple regression analyze with SPSS-23 software.

Results: Pearson correlation coefficient showed that there is a significant relationship between type D personality and it's sub-scales with depression in female students $(p<0.001)$. The results of regression analysis also showed that between the two components of type D personality, negative affect was good predictor of depression $(\mathrm{P}<0.001)$.

Conclusion: According to the results and the importance of adolescence, its necessary to consider Effective and suitable strategies in order to reduce negative affect, and enhance healthy social relations in families, Social and educational environments.

Keywords: Type D personality, Negative affect, Social inhibition, Depression, Female students 


\title{
بررسى رابطه تيٍ شخصيتى D و ابعاد آن با افسردكى در دانش آموزان دختر مقطع متوسطه دوم شهر ستان شاهينشهر
}

\author{
نعمتاله يارالهى "، مهتاب رحيمى ؛ آرام خباز شيرازى²

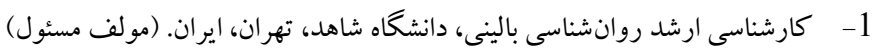 \\ n.yaralahi@yahoo.com \\ 2-دانشجوى كارشناسى ارشد روانشناسى بالينى، دانشگاه شهيد خمر ان، اهواز، ايران

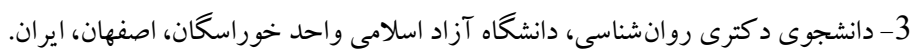

جـكيده

مقدمه: افسردگى يكى از شايع ترين و ناتوان كنندهترين مشكلات نوجو انان است. ئزوهشها نشان دادهاند كه عوامل شخصيتى مىتواند تغييرات خلقى را در طول زمان بيشيينى كنند و برخى تيّهاى شخصيتى نسبت به ابتلا به اختلالات روانى از ساير تيڤ ها مستعد تر هستند.

هدف: هدف از اين يُوهش، بررسى رابطه ميان تيب شخصيتى D و ابعاد آن با افسردگى در دانش آموزان دختر مقطع متوسطه دوم بود. روش: يُروهش حاضر يكك يزووهش توصيفى از نوع مقطعى است. جامعه آمارى شامل كليه دانش آموزان دختر مقطع متوسطه دوم

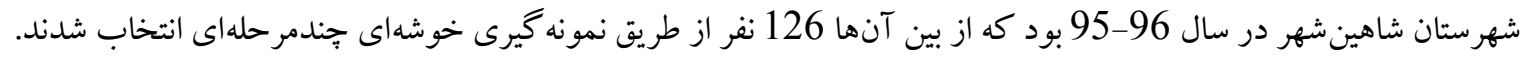

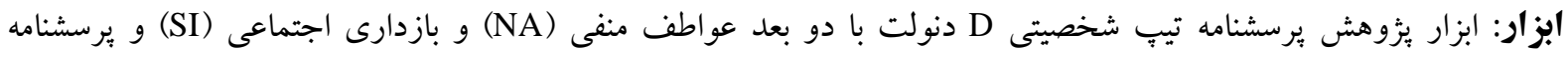

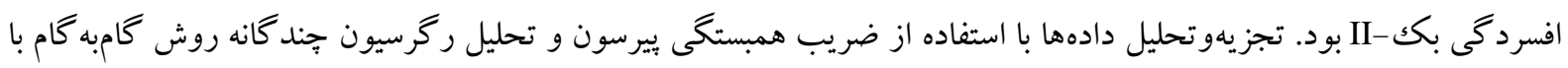
استفاده از نرمافزار SPSS-23 - انجام شد. يافته ها: نتايج نشان داد كه بين تيب شخصيتى D و هريك از ابعاد آن (NA و NI (SI) با افسردگى رابطه مثبت و معنادار وجود دارد (P<0/001). هم جنين، نتايج تحليل ركرسيون مشخص كرد كه از ميان مؤلفهاى تيب شخصيتى D، عواطف منفى مى تواند

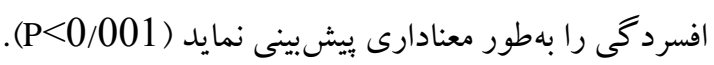

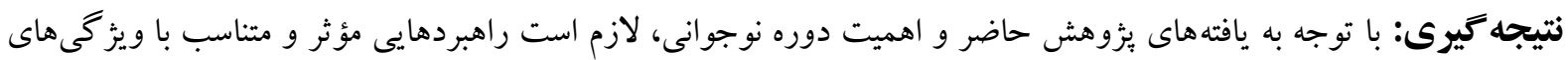
شخصيتى افراد جهت كاهش عو اطف منفى و تقويت روابط اجتماعى سالم در محيطهاى خانو ادگىى، اجتماعى و آموزشى آنان در نظر خرفته شود. كليد وازهها: تيب شخصيت D، هيجانات منفى، بازدارى اجتماعى، افسردگى، دانش آموزان دختر 
ياد مى كند، زيرا در اين مرحله تكامل يافته ترين خصوصيات انسانى ظاهر مىشود (احدى و جمهرى،

مسئله بيمارى روانى در آسيبشناسى نوجوانى حائز اهميت زيادى است؛ جراكه ويز گیى هاى رشدى دوره نوجوانى مىتواند زمينهاز بروز انواع اختلالات رفتارى، سوءمصرف مواد و بيمارىهاى روانى باشد. در سالهاى اخير مشاهده شده است كه شمار زيادى از نوجوانان از مشكلات عاطفى و روانى رنج مىبرند (سبهر منش و همكاران، 1387). مطالعهاى كه در سال

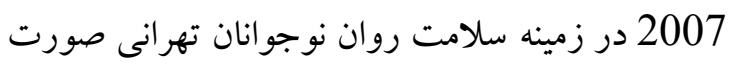
كرفت نشان داد كه 34/1 درصد دختران و 23/7 درصد از يسران بر اساس پرسشنامه GHQ-12 مشكو كك به اختلال بودند (امامى و همكاران، 2007). نكته بسيار مهم اين كه بسيارى از آسيبهاى روانى در دوران بزرگكسالى نيز، درواقع ادامه مشكلات دوران

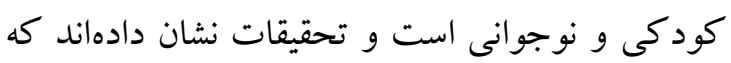
شروع بيمارى روانى در 50 درصد بزرگكسالان در ور دوران نوجوانى بوده است (بفلرّ، 2008). يكى از شايعترين و ناتوان كنندهترين مشكلات جوانان و نوجوانان افسردگى است (رستمزاده و خليل

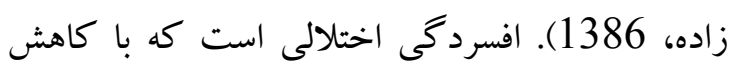
انرزى و علاقه، احساس كناه، اشكال در تمركز، بى اشتهايى و افكار مر گك و خود كشى مشخص مى شود احس

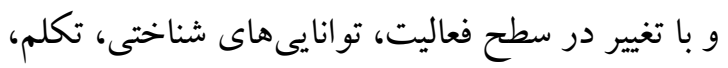
وضعيت خواب، اشتها و ساير ريتمهاى بيولوزيكك

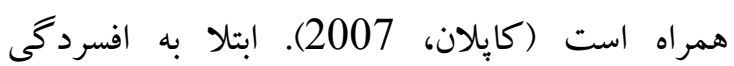

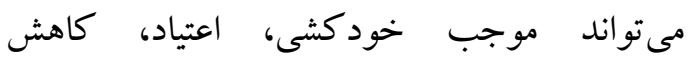
اعتمادبهنفس و نتايج حاصل از آن، افت تحصيلى و و درمجموع، اختلال در عملكردهاى شغلى، خانو ادكى و اجتماعى شود كه بهطور مستقيم و غيرمستقيم

3- Belfer
مقدمد

نوجوانى دوره انتقال از كودكى به بزرگكسالى و از

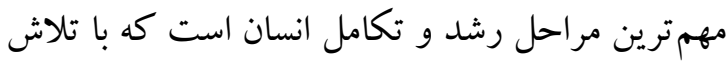

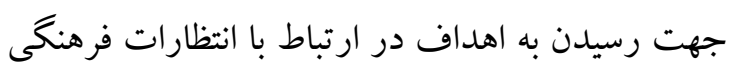
و جهشهاى رشد اجتماعى، عاطفى و جسمانى مشخص مى شود (رياسى و همكاران، 1391). رشد شخصيتى و شناختى نوجوان بهصورت تغييرات در

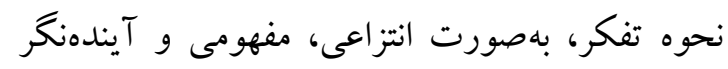
شدن است و بسيارى از نوجوانان در اين دوره خلاقيت قابلملاحظهاى از خود نشان مىدهند. طى اين دوره،

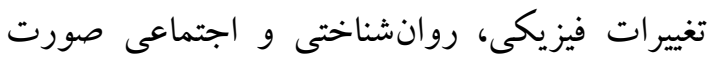

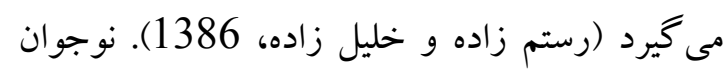
بهتدريج ارزشهاى گوناگونى را از منابع متفاوت وارد نظام اعتقادى خود مى كند و اين نظام اعتقادى براى

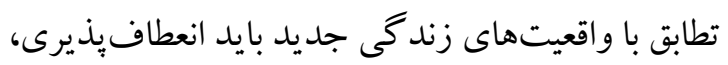

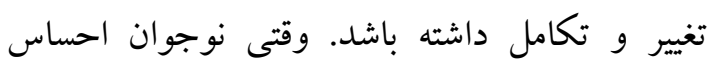
استقلال مى كند و خانو اده بختّكى و بالندگى در حال ظهور نوجوان را تشويق و حمايت مى كند، او براى اين

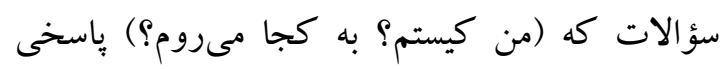
درخور مىيابد. تكليف عمده نوجوانان در اين دوره، كسب هويت و نوعى احساس اطمينان از خويشتن است

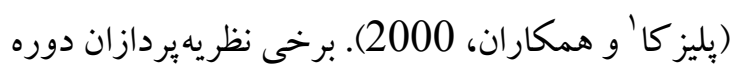
نوجوانى را يرتنش و توأم با شور و هيجان مىدانند.

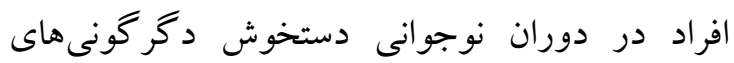
جشمخيرى مىشوند كه معمولاً نوسانهاى برشور عاطفى به دنبال دارد كه نوجوان را با احساسات متناقض و تحريكات فيزيولوزيكى و غيره روبه دورو مىسازد. استانلى هال، يدر روانشناسى بلوغ، براى بيان

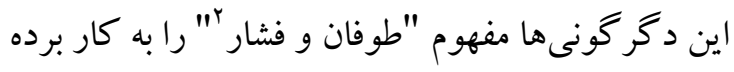

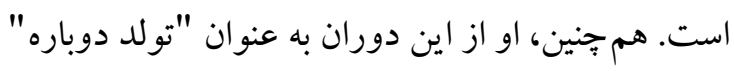


قلبى مرتبط است. براى مثال، با انجام يك بثزوهش بر روى 384 بيمار قلبى، مشخص شد كه يككسوم آنان نمرات بالايى را در تيب شخصيتى D كسب كردند. اين بيماران را 8 سال تحت نظر داشتند؛ در بايان مشاهده كردند كه 27 درصد آنها بر اثر سكته قلبى لـ فوت كردند، ولى از گروهى كه فاقد اين تيب بودند فقط 7 درصد با مرگك ناشى از سكته قلبى روبهرو شدند (دنولت، 1998؛ به نقل از احمد بور مباركه و

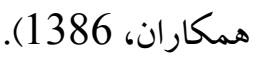

نقش آسيبزايى اين تيب شخصيتى در ابعاد روانشناختى و فيزيولوزيكى مبتنى بر دو ويز گیى كلى و ثابت شخصيتى است كه عبارتاند از عواطف منفى و بازدارى اجتماعى (دنولت، 2005). منظور از عواطف منفى، تمايل فرد به تجربه احساسات منفى در اوقات و

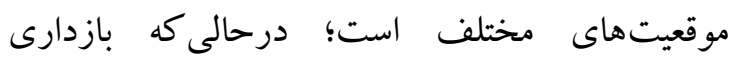
اجتماعى به تمايل فرد به اجتناب از ابراز اين هيجانات منفى در تعاملات اجتماعى اشاره دارد. نمره بالاى فرد

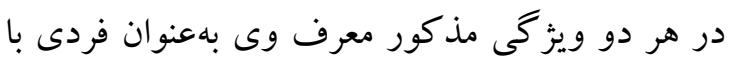
سنخ شخصيت D است. ازنقطهنظر بالينى افراد داراى تيب شخصيتى D مستعد نخرانى، تنش، احساس ناشادى

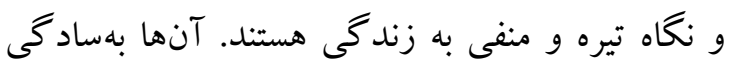
عصبانى مى شوند و در كل احساسات مثبت كمترى را تجربه مى كنند. اين افر اد درعين حال كه بهسادكى دجّار احساسات منفى مىشوند، به دليل ترس از طرد يا بعارزش شدن از بيان هيجانات خويش در تعامل با ديخران اجتناب مىورزند و بهعبارتديخر، احساسات خود را در درون خود مىريزند. بهطور كلى اين افراد ييوندهاى كمترى را با ديخران برقرار مى كنند و هنگام بودن با غريبهها احساس ناراحتى مى كنند و بنابراين، بيشتر هم منزوى هستند (يدرسن و و دنولت، 2003). شيوع اين تيب شخصيتى در جمعيت عمومى بين 13 تا

4- Pedersen
هزينهاى هنگفتى را به جامعه تحميل مىنمايد

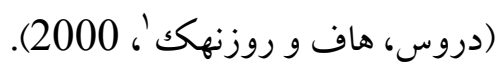

احتمال ابتلا به افسردگى از سنين كودكى تأنى كهن سالى وجود دارد، اما در اغلب اوقات شروع علائم در نوجوانى و اوايل جوانى است (نسبر بو همكاران، 1997). ميزان شيوع اين اختلال در زنان 1.5 تا 3

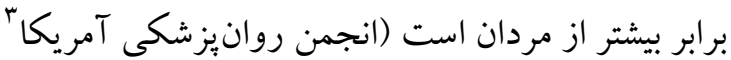

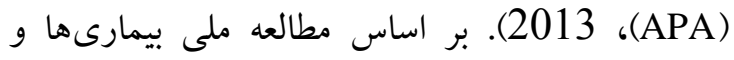

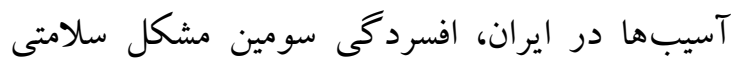
كشور است. در يُزوهشى كه به بررسى نظاممند مطالعات انجام شده (مجموعاً 56 مقاله) در زمينه افسردگى در ايران برداخت، يافتها نشان داد شيوع افسردگى در جمعيتهاى مختلف ايرانى از 5/69 تا درد 73 درصد متغير بود. علاوه بر اين، نتايج نشان داد

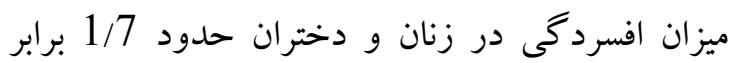
بيشتر از مردان؛ و در جمعيت روستايى و شهرهاى كو پك به نسبت شهرهاى بزرگك بيشتر بود (منتظرى و

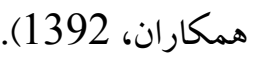
از سوى ديخر، مطالعات قبلى نشان دادهاند كه عوامل شخصيتى مىتواند تغييرات خلقى را در طول زمان بيشينى كنند. نوع تيب شخصيتى افراد با يكديگر متفاوت است و برخى تيبهاى شخصيتى نسبت به ابتلا به اختلالات روانى از ساير تيبها، مستعدتر هستند (باقريان سرارودى، 1388). در سالهاى اخير يكك سازه شخصيت جديد تحت عنوان سنخ شخصيت D مطرح شده است. اساس نظرى اين سنخ شخصيت حاصل يكك بررسى روى بيماران قلبى در بلزيكك بود كه در آن نقش ويز گیىهاى شخصيت در ييامدهاى بيمارى قلبى مورد مطالعه قرار

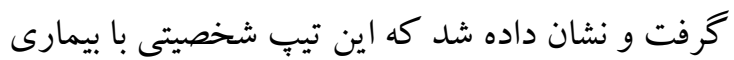

1- Druss, Hoff \& Rosenheck

2- Knesper

3- American Psychiatric Association (APA) 
و اقدام براى رفع آنها انعكاس بسيار مثبتى بر كار كرد

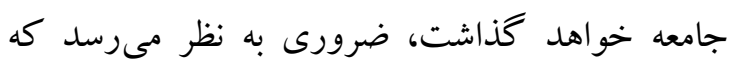

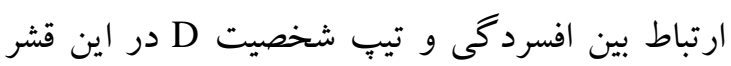

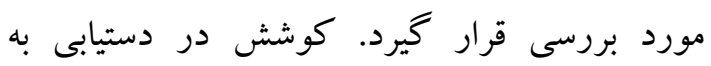
يافتهايى در اين حيطه مىتواند امكان درنظر كرفتن

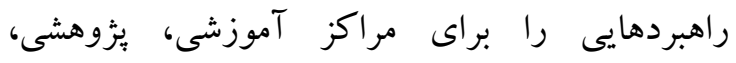

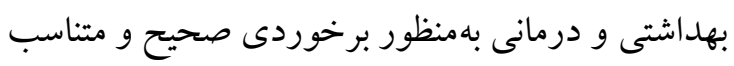
با ويز گى هاى شخصيتى اين افراد به همراه داشته باشد.

\section{روش}

يثوهش حاضر يكك ئزوهش توصيفى از نوع مقطعى است. جامعه آمارى اين يُزوهش شامل كليه دانش آموزان دختر مقطع متوسطه دوم شهرستان شاهينشهر بوده كه در سال تحصيلى 96-95 مشغول به تحصيل بودند. از اين ميان، تعداد 126 نفر از دانش

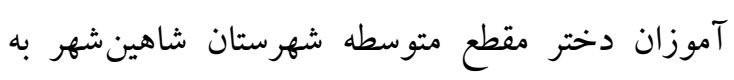

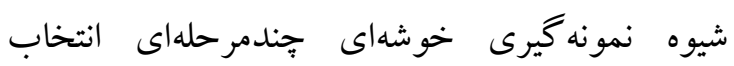

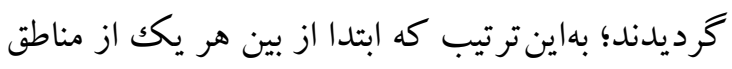
مختلف شهرستان يك مدرسه به شيوه تصادفى انتخاب و سبِ از ميان هر كدام از آنان جند كلاس بهطور تصادفى انتخاب شده و برسشنامهاى بُزوهش در ميان

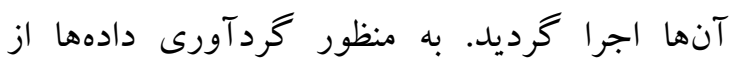

$$
\text { ابزارهاى زير استفاده گرديد: }
$$

الف: يرسشنامه تيب شخصيت D: اين مقياس در سال 2005 توسط دنولت تدوين شده است، شامل 14 آيتم بوده و مؤلفههاى عاطفه منفى (NA) و و و بازدارى

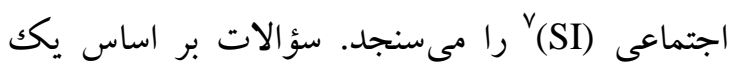
طيف ليكرت 5 درجهاى بهصورت "كاملاً غلط" "تقريباً غلط"، "بينابين" و "تقريباً صحيح" و "كاملاً صحيح" نمره كذارى مىشوند. حداقل و حداكثر نمرات اين مقياس به ترتيب 14 و 56 است (13).
32/5 درصد و در بيماران قلبى-عروقى بين 26 تا 53 درصد گزارششده است (كوير' و همكاران، 2007؛ كندراس 'و همكاران، 2006). تيب شخصيت D بهعنوان يك عامل خطر مرتبط

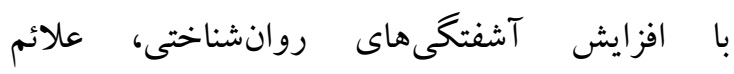

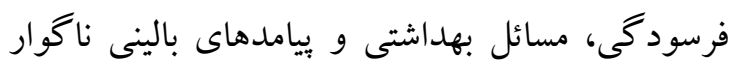
(باوجود درمان مناسب) معرفى شده است (دنولت،

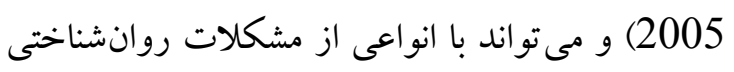

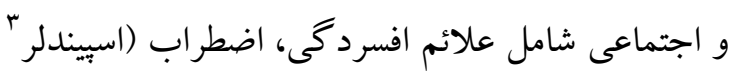
و همكاران، 2009)، اختلال استرس يس از وانم سانحه (يدرسن و همكاران، 2004)، خشم، تنش مزمن، بدبينى و اعتمادبهنفس وِيايين (يدرسن و و دنولت،

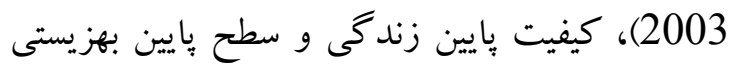
روانى (يله "ُ و همكاران، 2010) ارتباط داشته باشد.

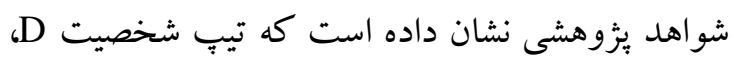
افسردگى را تا 5 سال بعد در يكك گرووه آميخته از

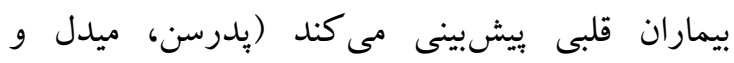
لارسن، 2002).

بنابراين، با توجه به شواهد يُزوهشى موجود در مورد

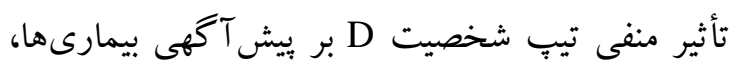
درك بهتر سازو كارهايى كه مىتوانند رابطه بين اين تيبّ شخصيتى و بيامدهاى آن را بر سلامت فرد توضيح

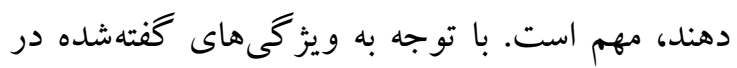

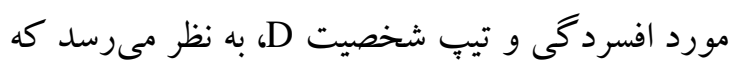
ميان آنها ارتباط وجود داشته باشد. علاوه بر اين، ازآنجايى كه رابطه ميان اين دو متغير در ميان افراد

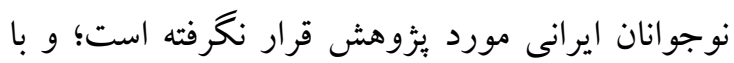

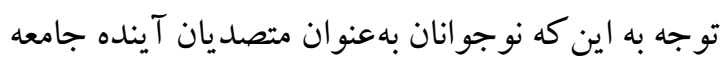
از اهميت ويزهاى برخوردارند و بررسى مشكلات آنان

1- Kupper

2- Conraads

3- Spindler

4- Pelle

5- Middel , \& Larsen 
كه اين يرسشنامه از اعتبار و روايى مطلوبى برخوردار

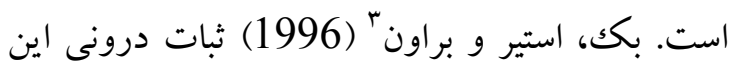

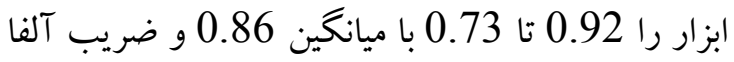

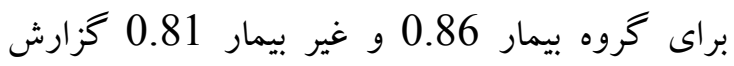
كردماند. دابسون و محمدخانى (1386) نيز ضريب آلفاى 0.92 براى بيماران سريايى و 0.93 براي 0.93 دانشجويان و ضريب باز آزمايى به فاصله يك هفته را

$$
0.93 \text { به دست آوردند. }
$$

لازم به ذكر است تجزيه و تحليل دادهها با استفاده

از ضريب همبستخى بيرسون (بررسى رابطه ميان تيب

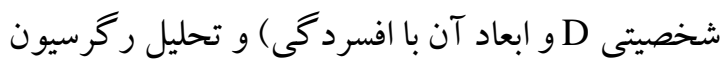

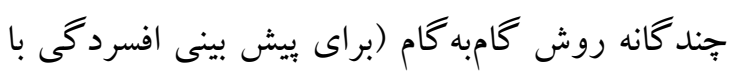
استفاده از متغيرهاى بيش بين) با استفاده از نرمافزار SPSS

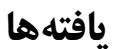

اين مطالعه بر روى دانش آموزان دختر مقطع متوسطه دوم شهر ستان شاهين شهر انجام گرفت. ميانكين سنى نمونه يُوهش برابر 16.4 و انحراف معيار آن

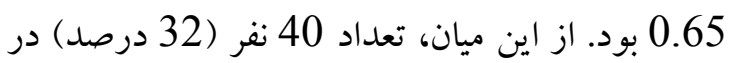
رشته علوم انسانى، 55 نفر (43 درصد) در رشته علوم

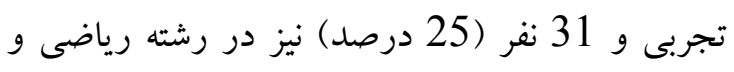
فيزيك مشغول به تحصيل بودند. براى بررسى رابطه بين شخصيت D و هر يك از

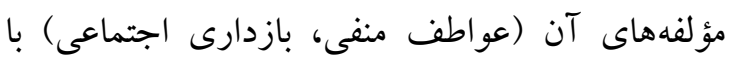

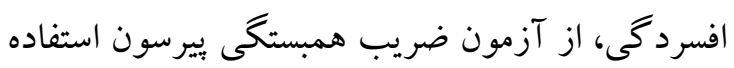
شد (جدول 1). با توجه به جدول 1، بين متغيرهاى تيب إني

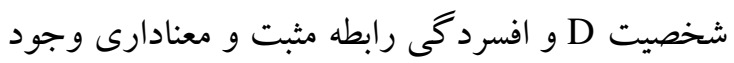

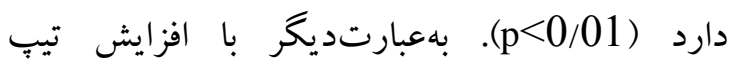

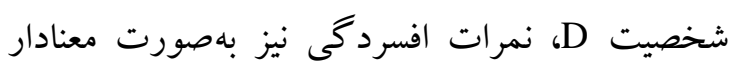

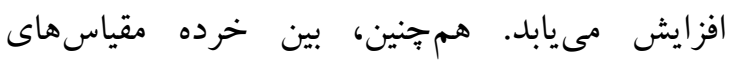

3- Steer, \& Brown
ضريب ૧ايايى با استفاده از باز آزمايى براى عاطفه منفى

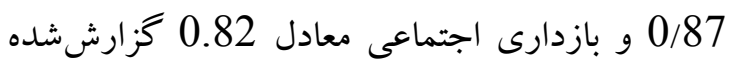
است (هسن' و همكاران، 2005). ويزگكىهاى روانسنجى اين برسشناهه در مطالعات داخلى نيز مناسب و مطلوب گزارش شده است (ايلبيخى، ابو القاسمى و رستمى، 1393 1393.

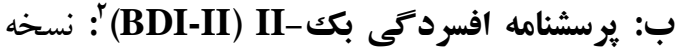

اوليه اين يرسشنامه (BDI-I) توسط آرون بك در دهه بكامه

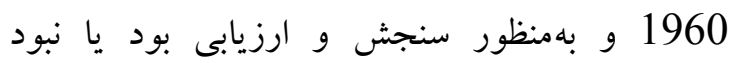
افسردگى و نيز شدت آن در بزر كُسالان و نوجوانان

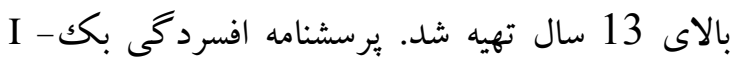
درسال 1971 مورد تجديدنظر و نهايتاً در سال 1979 نسخه جديد آن انتشار يافت. طى سالهاى اخير، BDI هذيرفته ترين ابزار شناسايى شدت افسردگى در بيمارانى بوده كه تشخيص افسردگى بالينى رادئ دريافت

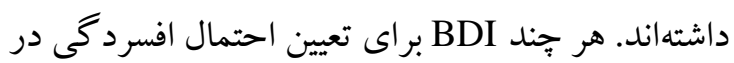
جمعيت بهنجار نيز كاربرد دارد. اين برسشنامه داراى

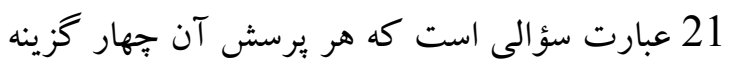

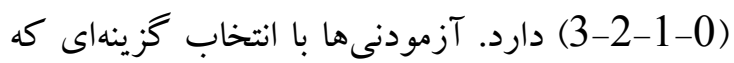
با احساسشان در آن هفته متناسبتر است، به سؤالات باسخ مىدهند. 15 عبارت يرسشناهه مربوط به علائم

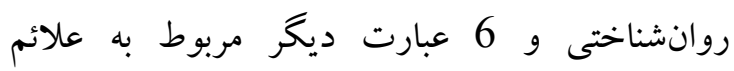

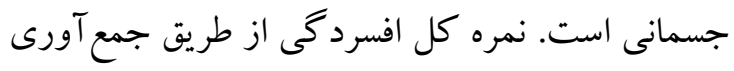
نمرات بهدست آمده از تمام عبارت ها محاسبه مى شیود و و

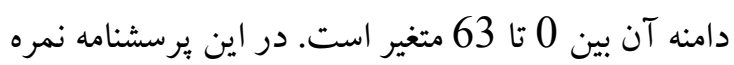

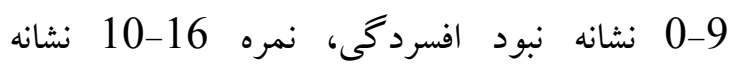

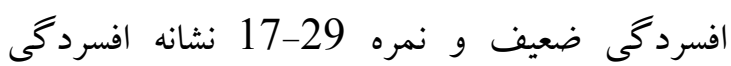
متوسط است و نمرات بالاتر از 30 گوياى افسردخى شديد است (دابسون و محمدخانى، 1386). مطالعات روانسنجى انجام شده بر روى بك- II نشان مىدهد (دابسون 
افزايش نمرات مربوط به عواطف منفى و بازدارى

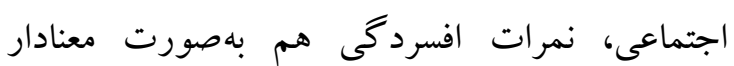

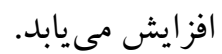

عواطف منفى و بازدارى اجتماعى با افسردگى رابطه

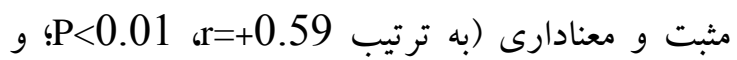

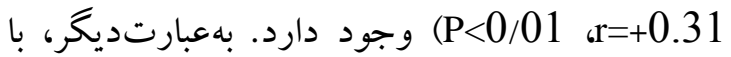

\begin{tabular}{|c|c|c|c|c|}
\hline Dخصيت D & بازدارى اجتماعى & عواطف منفى & افسردگى & متغ \\
\hline & & & 1 & افسردگى \\
\hline & & 1 & $0.49^{* * *}$ & عواطف منفى \\
\hline & 1 & $0.59^{* * *}$ & $0.31^{* * * *}$ & بازدارى اجتماعى \\
\hline 1 & $0.84^{* * *}$ & $0.93^{* * *}$ & $0.47^{\text {w** }}$ & Dخصيت D \\
\hline
\end{tabular}

عواطف منفى يگانه بيشبينى كننده نمرات افسردگى

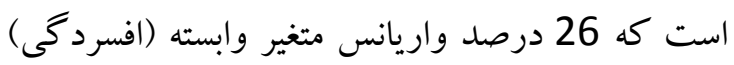
را تعيين مى كند؛ و متغير بازدارى اجتماعى قادر به ييشبينى افسردگى نبود.
به منظور تعيين سهم هر يكك از مؤلفهاى عواطف

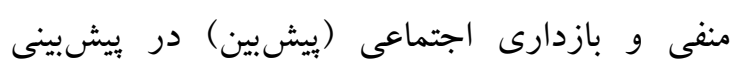
افسردگى دانش آموزان (ملاكك)، متغيرهاى ياد شده آندي

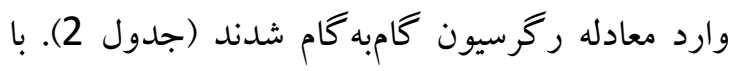
توجه به نتايج جدول 2 و معنادار بودن نسبت F، مؤلفه

جدول 2: نتايج تحليل رگرسون جندمتغيرى Fام به كام مربوط به افسردىى، تيب شخصيتى D، عواطف منفى و بازدارى اجتماعى

متغير ملاكك

واريانس مربوط به نمرات افسردگى را تبيين مى كند؛

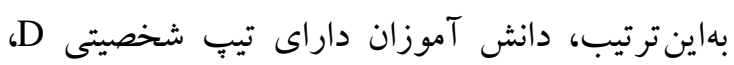
يعنى كسانى كه هيجانات منفى بيشترى را تجربه

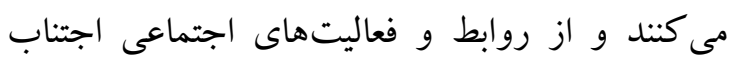

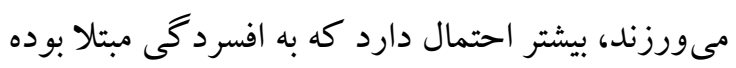
و يا در معرض آن قرار داشته باشند.

اين نتيجه با يافتهاى يثروهش اربابى (1392) همخو انى دارد كه رابطه ميان افسردگى، اضطراب و ونئه
هدف يثزوهش حاضر بررسى رابطه ميان تيب

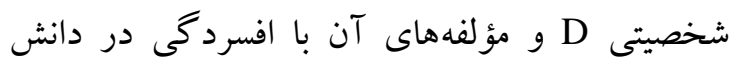
آموزان دختر مقطع متوسطه دوم بود. همانطور كه ملاحظه شد، يافتها نشان داد كه تيب شخصيتى D و مؤلفههاى آن (هيجان منفى و بازدارى اجتماعى) با يال افسردگى رابطه مثبت و معنادارى دارند. هم جنين، نتايج نمايان ساخت كه عواطف منفى حدود 26 درصد از 
احتمالاً خود را درگير مسائل منفى و نامطلوب مىسازند كه نتيجه آن داشتن نكرش منفى نسبت به خود و ديخران است (يدرسون و همكاران، 2004). از سوى ديخر، افراد داراى تيب شخصيتى D ديد منفى ديخ نسبت به خود دارند و جهان را سرشار از مشكلات قريبالوقوع تصور مى كنند. اين افراد در تعاملات اجتماعى احساس نا امنى و تنش مى كنند، از اين رو

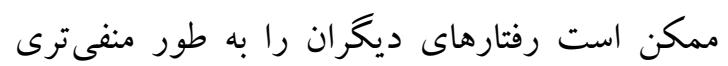
تفسير كنند، همجينين تمايل دارند تا به طور منفى ترى در برابر ديخران واكنش نشان دهند. بنابراين افراد

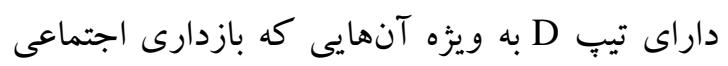

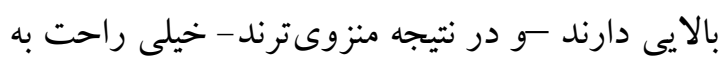

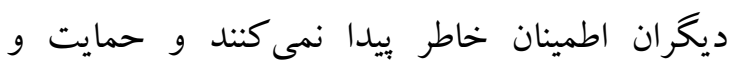
باداشهاى اجتماعى كمترى ران دريافت مى كنند

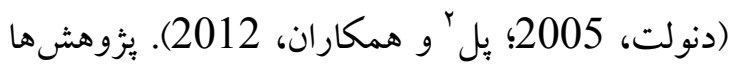

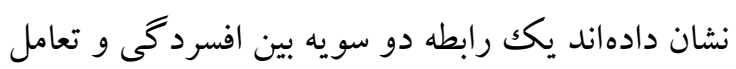
اجتماعى برقرار است و افسردگى از كمبود حمايت

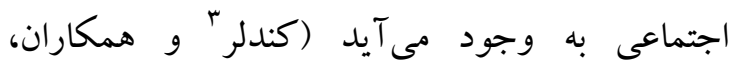

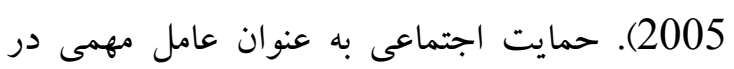
غلبه بر تنش زاها مطرحشده است كه مىتواند رابطه بين استرس- بيمارى را تعديل كند و تأثيرات منفى بنى

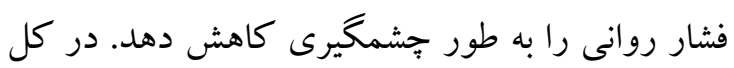
عوامل اجتماعى مى تواند تأثير شايانى در عود دورههاى روني افسردگى و ايجاد آن در افراد مستعد دارد (روشن جسلى، 1394). ارتباطات نزديكك و حمايت اجتماعى إنى را كه خانواده، دوستان، همكاران و جامعه فراهم

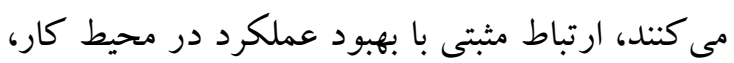

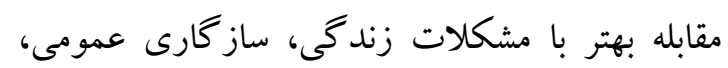

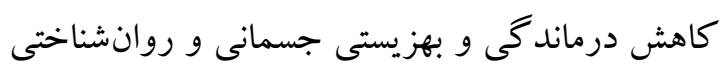
دارد (اسدى و همكاران، 1392).

2- Pell

3- Kendler
استرس با تيب شخصيتى D را در افراد معتاد و غير معتاد بررسى نموده بود و به اين نتيجه رسيد كه بين تيب شخصيتى D با افسردگى، اضطراب و استرس در افراد معتاد و غير معتاد رابطه مثبت و معنادارى داشت. همجنين، يافته هاى ئزوهش حاضر با نتايج حاصل از يزّوهش بخشايش و دهقانى (1392) همخوانى دارد كه رابطه تيٍ شخصيتى D با سبككهاى مقابله و سلامت عمومى را بر روى دانشجويان بررسى كردند و نتيجه كرفتند كه افراد با تيب شخصيتى D نسبت به افراد با تيب غير D سلامت عمومى يايينترى دارند و بيشتر از سبكك مقابلهاى هيجانمدار استفاده مى كنند. ازاينرو، به نظر مىرسد تيب D مىتواند تأثير مهمى بر سطح سلامت عمومى و به كاركيرى نوع سبكهاى مقابله داشته باشد. علاوه بر اين، اسدى و همكاران D (1392) در يُزوهشى با عنوان رابطه تيّ شخصيت و فشار روانى ادراككشده در دانشجويان دريافتند كه افراد داراى تيبّ شخصيت D سطوح بالاى فشار روانى را تجربه مى كنند و هردو بعد هيجانات منفى و بازدارى اجتماعى با فشار روانى ادراككشده بالاترى همراه

در تبين اين يافتها مىتوان كفت كه به دليل آن كه افر اد با تيب شخصيتى D به تجربهُ هيجانات منفى از قييل غمكگينى، اضطراب، خشم، احساسات خصمانه همراه با بازدارى اين هيجانات هنگام اجتناب از تماسهاى اجتماعى گرايش دارند تا هيجانات مثبت، بنابراين احتمالاً بيشتر دجار مشكاتلات عاطفى از قبيل نكرًانى و افسردگى و بيمارىهاى روانتى مىشوند (دى فرويت' و دنولت، 2002) كه اين امر خود مى تواند بر روى خلق وخو و ارتباطات اجتماعى فرد اثر كذاشته و شرايط را براى ابتلا به بيمارىهاى خلقى نظير افسردگى مهيا سازد. اين افراد بهجاى تفكر مثبت 
دارند و مؤلفه عواطف منفى حدود 26 درصد از

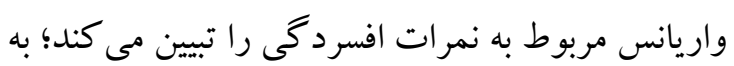
اين ترتيب، دانش آموزان داراى تيب شخصيتى D، يعنى

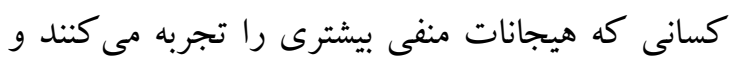
از روابط و فعاليتهاى اجتماعى اجتناب مىورزند،

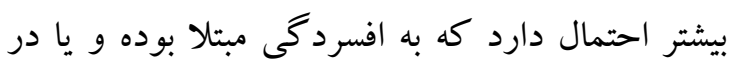

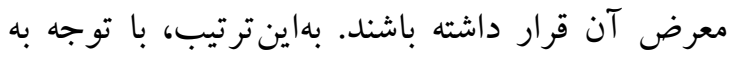

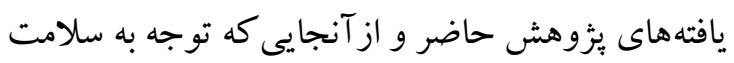
روانشناختى نوجوانان بهعنوان آيندهسازان جامعه از اهميت ويزهاى برخوردار است، لازم است راهبردهايى

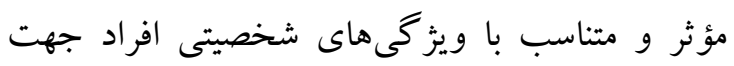
كاهش عواطف منفى / افزايش عو اطف مثبت و تقويت روابط اجتماعى سالم در محيطهاى خانوادگى، اجتماعى و آموزشى آنان در نظر كرفته شود.

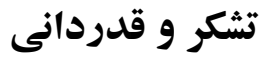

$$
\begin{aligned}
& \text { نويسند كان مقاله بر خوران خود لازم مىدانند از } \\
& \text { دبير ستانهاى شهرستان شاهين شهر و همه دانش آموزانى } \\
& \text { كه با كشادهرويى در يزوهش حاضر شركت كردندان } \\
& \text { صميمانه تشكر و قدردانى نمايند. }
\end{aligned}
$$

\section{References}

Ahadi, H., Jamhari,F. (2016). Growth psychology (adolescence, adulthood). 7th edition, Tehran: Ayandeh publication. (Persian)

Ahmadpour, M. A., Ahadi, H., Mazaheri, M. A., \& Nafisi, Gh. (2007). Building and validation a scale to measure the type D personality and its relationship with coronary heart disease. Knowledge and Research in applied Psychology (Khorasgan), (32), 37-60. (Persian)

American Psychiatric Association (2013). Diagnostic and Statistical Manual of Mental Disorders (DSM-5). Translated by Rezaee. F. and other (2015). Tehran: Arjmand publication. (Persian)

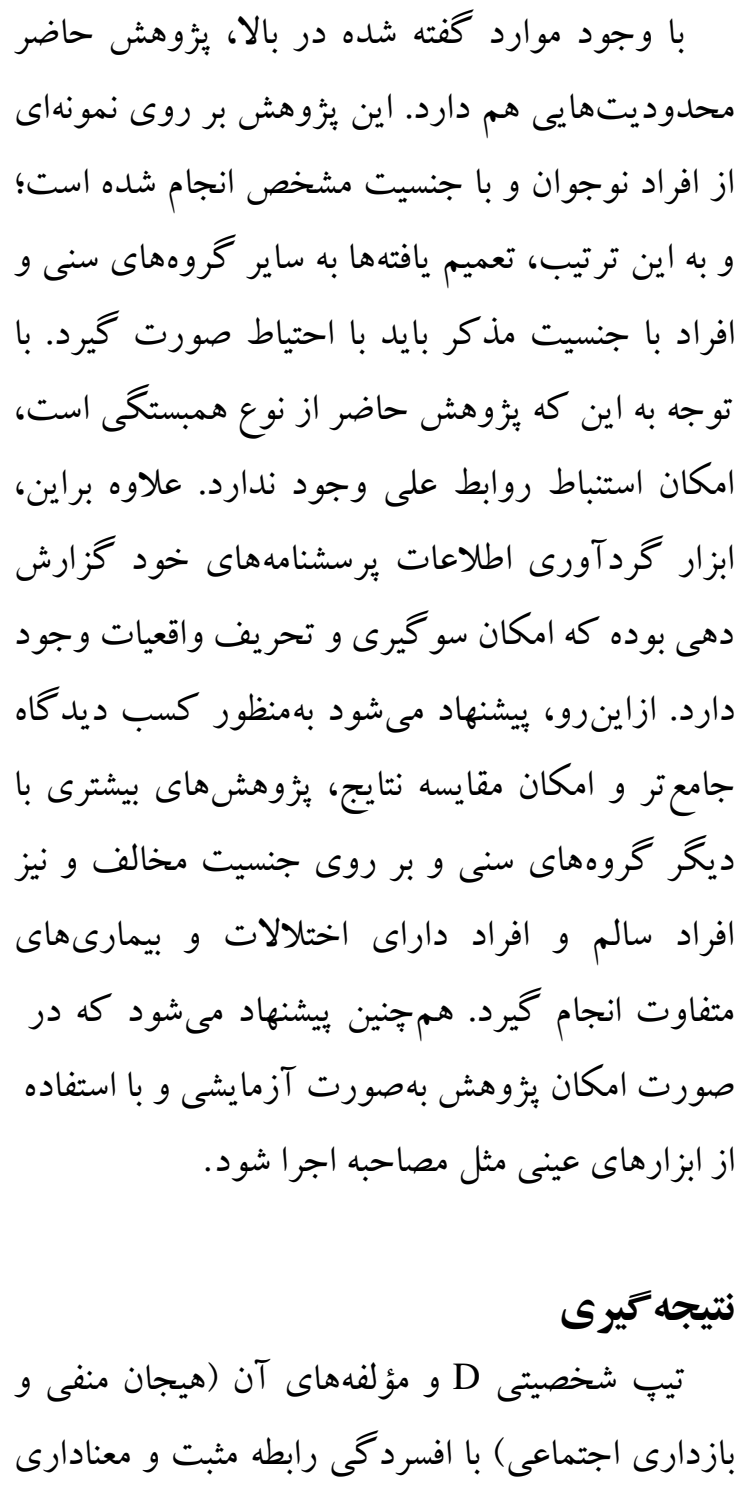

Arbabi, S. (2013). Relationship between D-type personality type with depression, anxiety and stress in addicted and non-addicted people in Zahedan city. University of Sistan and Baluchestan, Master's thesis. (Persian)

Asadi, M. S., Bakhsipour, R., \& Poursharifi, H. (2013). Relationship between type $\mathrm{D}$ personality and its dimensions with perceived stress in students of Tabriz University. Knowledge and Research in applied Psychology (Khorasgan), 14 (2), 91-98. (Persian)

Bagherian Sararoodi, R. (2009). Type D personality .Researches of behavior sciences. 7 (1). 76-87. (Persian) 
Bakhshayesh, A., \& Dehghani, F. (2013). Investigating the relationship between type D personality, coping styles and general health. Clinical Psychology and Personality, 20 (9). (Persian)

Beck, A. T., Steer, R. A., \& Brown, G. K. (1996). Beck Depression Inventory-II (BDI-II). San Antonio, TX: Psychological Corporation.

Belfer, M. L. (2008). Child and adolescent mental disorders: the magnitude of the problem across the globe. Journal of Child Psychology and Psychiatry, 49(3), 226-236.

Cavanagh, S. J., \& Snape, J. (1997). Educational sources of stress in midwifery students. Nurse Education Today, 17(2), 128-134.

Conraads, V. M., Denollet, J., De Clerck, L. S., Stevens, W. J., Bridts, C., \& Vrints, C. J. (2006). Type D personality is associated with increased levels of tumour necrosis factor (TNF)- $\alpha$ and TNF- $\alpha$ receptors in chronic heart failure. International journal of cardiology, 113(1), 34-38.

Dabson, K. S., \& Mohammad Khani, P. (2007). Psychometric characteristics of Beck depression inventory-II in patients with major depressive disorder. Rehabilitation, 8 (29), 80-86. (Persian)

De Fruyt, F., \& Denollet, J. (2002). Type D personality: A five-factor model perspective. Psychology and Health, 17(5), 671-683.

Denollet, J. (1998). Personality and risk of cancer in men with coronary heart disease. Psychological Medicine, 28,991995.

Denollet, J. (2000). Type D personality: a potential risk factor refined. Journal of psychosomatic research, 49(4), 255-266.

Denollet, J. (2005). DS14: standard assessment of negative affectivity, social inhibition, and Type D personality. Psychosomatic medicine, 67(1), 89-97.

Druss, B. G., Hoff, R. A., \& Rosenheck, R. A. (2000). Underuse of antidepressants in major depression: prevalence and correlates in a national sample of young adults. The Journal of clinical psychiatry.

Emami H.Ghazinour M. Rezaeishiraz H. Richter J. (2007). Mental health of adolescents in Tehran, Iran. $\mathbf{J}$ Adolesc health.;41(6):571-6. (Persian)

Hansen, P. E., Floderus, B., Frederiksen, K., \& Johansen, C. (2005). Personality traits, health behavior, and risk for cancer. Cancer, 103(5), 1082-1091.

Heaven, P. (2002). Adolescent health: The role of individual differences. Psychology Press.

Ilbeigy, Gh. R., Abolghasemi, A., Rostami, M. (2014). Role of HEXACO personality dimensions, D Personality Type and emotions in the quality of life of people suffering from cancer. Journal of Torbat Heydariyeh University of Medical Siences; 2(3): 10-21. (Persian)

Kendler, K. S., Myers, J., \& Prescott, C. A. (2005). Sex differences in the relationshipbetween social support and risk for majordepression: A longitudinal study of opposite-sextwin pairs. American Journal of Psychiatry, 162(2),250-256

Kenny, D. T., Kenny, D., \& Job, R. F. S. (Eds.). (1995). Australia's Adolescents: A health psychology perspective. University of New England.

Knesper D, Rtba M, Schwenk,T (1997). Primary care psychiatry. Ist ed. Pliladelphia. WB Saunders

Kupper, N., Denollet, J., De Geus, E. J., Boomsma, D. I., \& Willemsen, G. (2007). Heritability of type-D personality. Psychosomatic Medicine, 69(7), 675-681.

Montazeri, A., Mousavi, J., Omidvari, S., Tavousi, M., Hashemi, A., Rostami, T. (2013). Depression in Iran: a systematic review of the literature (2000-2010). Payesh: Journal of the Iranian Institute for Health Sciences, 567-594. (Persian)

Pedersen, S. S., \& Denollet, J. (2003). Type D personality, cardiac events, and impaired quality of life: a review. European journal of 
cardiovascular

prevention

\&

rehabilitation, 10(4), 241-248.

Pedersen, S. S., Middel, B., \& Larsen, M. L. (2002). The role of personality variables and social support in distress and perceived health in patients following myocardial infarction. Journal of Psychosomatic Research,53(6), 11711175.

Pedersen, S. S., van Domburg, R. T., Theuns, D. A., Jordaens, L., \& Erdman, R. A. (2004). Type D personality is associated with increased anxiety and depressive symptoms in patients with an implantable cardioverter defibrillator and their partners. Psychosomatic medicine, 66(5),714-719.

Schiffer, A.A., Pedersen, S. S., Widdershoven, J. W., \& Denollet, J. (2008). Type D personality and depressive symptoms are independent predictors of impaired health status in chronic heart failure. European journal of heart failure, 10(8), 802-810.

Pell, A.J., Van den Broek, K.C., \& Denollet, J. (2012). Interventions in the context of the distressed (Type D) Personality. in: Ellen A, Dornelas, stress proof the heart: behavioral interventions for cardiac patient. (167-198). New York: springer publishing.

Pelle, A. J., Schiffer, A. A., Smith, O. R., Widdershoven, J. W., \& Denollet, J. (2010). Inadequate consultation behavior modulates the relationship between Type D personality and impaired health status in chronic heart failure. International journal of cardiology, 142(1), 65-71.

Pliszka, S. R., Sherman, J. O., Barrow, M. V., \& Irick, S. (2000). Affective disorder in juvenile offenders: A preliminary study. American Journal of Psychiatry, 157(1), 130-132.

Rahnamay N. M. (2012). Comparison of depression in students of Islamic Azad University living in Takestan, Abhar, and Bouin-Zahra dormitories (2009). The Journal of Qazvin University of Medical Sciences (JQUMS), 16 (2), 83-86. (Persian)
Riasi, H. R., Mogharrab, M., Salehi Abarqui, M., Hassanzadeh Taheri, E., \& Hassanzadeh Taheri, M. M. (2012). A comparative study of depression in gifted and normal students in Birjand city during 2008-2009 school year. Modern Care Journal, 9(2), 95-103. (Persian)

Roshan, C. R. \& Colleges (2016). Abnormal psychology based on DSM-5. Ebne Sina Publication, Tehran, Iran.

Rostamzadeh, Z., \& Khalilzadeh, R, (2007). Prevalence and severity of depression among high school students in Urmia. Journal of Urmia Nursing and Midwifery Faculty, 5 (2), 12-18. (Persian)

Sadock, V. A. (2007). Kaplan \& Sadock's Synopsis of Psychiatry: Behavioral Sciences. Clinical Psychiatry. Translated by Farzin Rezai. Tehran: Arjmand publication. (Persian)

Sepehrmanesh, Z., Ahmadvand, A., Yavari, P, \& Saee, R. (2007). Mental Health of high school adolescents in Kashan in 2004. Iranian Journal of Epidemiology. 4 (2), 43-49. (Persian)

Spindler, H., Kruse, C., Zwisler, A. D., \& Pedersen, S. S. (2009). Increased anxiety and depression in Danish cardiac patients with a type D personality: crossvalidation of the Type D Scale (DS14). International journal of behavioral medicine, 16(2), 98-107. 